BACKGROUnD: Peripheral blood $\mathrm{CD8}^{+} \mathrm{T}$ cells expressing interferon gamma and interleukin- 4 (IL-4), and lacking CD28 molecules, were responsible for the dynamic interplay between peripheral blood and inflammatory sites.

Introduction: The aim of the current study was to define in Behçet's disease (BD), $\mathrm{CD8}^{+}$T-cell subsets using CD28 and CD11b monoclonal antibodies, and the characterization of the $\mathrm{Tc1} / \mathrm{Tc} 2$ ratio and perforin expression.

Methods: Flow cytometry was used for intracytoplasmic cytokines and perforin expression. Effector cells were investigated by adhesion of $\mathrm{CD8}^{+} \mathrm{T}$ cells to human microvascular endothelial cells and by chemotaxis using $\beta$-chemokine.

Results: Interferon-gamma-producing $\mathrm{CD8}^{+} \mathrm{T}$ cells in active and remission $\mathrm{BD}$ patients were increased, which induce a significant increase of the Tc1:Tc2 ratio in $\mathrm{BD} . \mathrm{CD8}^{+} \mathrm{CD28}^{-} \mathrm{CD11b}^{+}$T cells were found to be more expanded in BD patients than in agematched healthy controls. The expression of CD11b molecules in active $\mathrm{BD}$ allowed to $\mathrm{CD8}^{+} \mathrm{CD28}^{+} /$ $\mathrm{CD8}^{+} \mathrm{CD28}^{-}$subsets to adhere to human microvascular endothelial cells, with more efficiency in BD. Using MIP-1 $\alpha$, we observed that the migratory process of $\mathrm{CD28}^{-} \mathrm{CD}^{-} \mathrm{bb}^{+}$is more important in $\mathrm{BD}$. $\mathrm{CD28}^{-} \mathrm{CD11b}^{+}$exhibited an increased perforin expression in BD patients.

Conclusion: Taken together these results suggest the presence of immune activation, probably in response to a profound inflammation affecting $B D$ patients. The physiopathological significance of these results were toward autoimmune diseases and/or infectious process.

Key words: Behçet's disease, CD8 T cells, Inflammation, MIP-1 $\alpha$, Human microvascular endothelial cells

\section{Tc1/Tc2 ratio in the inflammatory process in patients with Behçet's disease}

\author{
Habib Houman ${ }^{1}$, Agnes Hamzaoui ${ }^{2,4}$, \\ Imed Ben Ghorbal ${ }^{1}$, Monia Smiti Khanfir ${ }^{1}$, \\ Moncef Feki ${ }^{3}$ and Kamel Hamzaoui ${ }^{4, C A}$
}

${ }^{1}$ Department of Internal Medicine, and ${ }^{3}$ Department Clinical Biochemistry, La Rabta Hospital, Tunis, Tunisia; ${ }^{2}$ Pneumology Hospital A. Mami, Department of Respiratory Diseases, Ariana, Tunisia; ${ }^{4}$ Medicine University of Tunis, Homeostasis and Cell Dysfunction, Unit Research 99/UR/08-40, Secrétariat d'Etat à la Recherche Scientifique et à la Technologie, Tunis, Tunisia

\author{
${ }^{\mathrm{CA}}$ Corresponding Author \\ Medicine University Tunis \\ 15, Rue Djebel Lakdar 1007 Tunis, Tunisia \\ E-mail: Kamel.Hamzaoui@fmt.rnu.tn
}

\section{Introduction}

Behçet's disease (BD) is an inflammatory multisystemic disorder with mucocutaneous, ocular, arthritic, vascular and central nervous system involvement. ${ }^{1} \mathrm{BD}$ is characterized by spontaneous remissions and relapses similar to those of various autoimmune diseases. Neutrophil hyperactivity with increased superoxide production, phagocytosis, release of enzymes and the implication of Heat-shock proteins in BD suggest an activated innate immunity. ${ }^{2}$ Investigation of the aetiology of $\mathrm{BD}$ has focused predominantly on herpes simplex virus immunopathology, streptococcal infection, and autoimmunity to oral or cross-reactive microbial antigens. ${ }^{3,4}$ Only $\mathrm{CD}^{+}$cells and Th1/Th2-type immune responses were currently investigated in cell-mediated immunity and inflammation in $\mathrm{BD} ;{ }^{5-7} \mathrm{CD} 8^{+}$T-cell subsets and Tc1/Tc2 cytokine expression were scarcely reported.
In a number of situations ranging from chronic inflammatory conditions, infectious ${ }^{8,9}$ to autoimmune diseases, ${ }^{10}$ a dysregulation in $\mathrm{CD}^{+}{ }^{+} \mathrm{T}$ cells by lacking CD28 molecule (costimulatory molecule) and expression of $\mathrm{CD} 11 \mathrm{~b}$ marker ( $\beta 2$ integrin $\alpha$-chain) was reported. $\mathrm{CD}^{+} \mathrm{CD}^{-} 8^{-} \mathrm{T}$ cells are characterized by morphological and functional features of activated/ memory $\mathrm{T}$ cells. ${ }^{11} \mathrm{CD} 11 \mathrm{~b}$ marker expression can distinguish between memory-type and effector-type $\mathrm{T}$ cells in human $\mathrm{CD} 8^{+} \mathrm{CD} 28^{-}$T subsets. ${ }^{12}$ Perforin, a pore-forming protein stored intracellulary that is produced by natural killer cells, gamma/delta $(\gamma / \delta)$ cells and $\mathrm{CD}^{+}{ }^{+} \mathrm{T}$ lymphocytes has been reported in elevated concentrations in several chronic inflammatory disorders. ${ }^{13}$ Perforin can induce apoptosis in a number of cells and thus might also play a role in the resolution of inflammatory responses by eliminating inflammatory or virally infected cells. ${ }^{14,15}$

The aim of the current study was to define the Tc1/Tc2 ratio, the pattern of expression of CD28, 
CD11b monoclonal antibodies on $\mathrm{CD}^{+}{ }^{+} \mathrm{T}$ cells, and the function of $\mathrm{CD}^{+}$naïve/memory effector cells in peripheral blood from $\mathrm{BD}$.

\section{Materials and methods}

\section{Patients and control subjects}

Patients with BD (five females and 31 males) were studied during the clinically active stage. The mean age of active BD was 32 years (range, 27-52 years) and the mean duration of disease was 74 months (range, 10-168 months). All active BD patients were showing at least three of the four major symptoms, including recurrent aphthous stomatitis, uveitis, genital ulcers, and skin lesions (erythema nodosum, folliculitis or subcutaneous thrombophlebitis). Peripheral blood was obtained from BD in the active stage before treatment, and clinical activity was assessed at the time of venipuncture for activity signs and symptoms (clinical criteria defined by the International Study Group). ${ }^{16}$ Nine BD patients have pulmonary manifestations (chronic cough, pulmonary aneurysms) and 12 other BD patients were diagnosed as having progressive neuro-Behçet's (persistent and progressive central nervous system manifestations for at least 1 year). After venipuncture, active $\mathrm{BD}$ patients received treatments, including steroids and colchicine. Remission BD group was composed of asymptomatic patients (mean duration of remission, 2 months). Their mean age was 39 years (range, 36-50 years). No patient was studied in both stages. Twenty healthy volunteers, composed of laboratory personnel (mean age, 42 years; range, 22-50 years), participated after giving informed consent. At the time of venipuncture, none of the blood donors had been receiving any medication or had an overt infection. The design of the study was approved by our National Ethics Committee.

\section{Cell preparation}

Mononuclear cells were separated from heparinized venous blood that was mixed with $20 \mathrm{ml}$ of Hanks's balanced salt solution (Gibco, Grand Island, NY, USA), using Ficoll-Paque (Pharmacia, Uppsala, Sweden) density gradient centrifugation. The cells were washed twice in phosphate-buffered saline (PBS), and then resuspended in PBS supplemented with $5 \%$ foetal calf serum. The former cell suspensions were finally adjusted to a concentration of $2 \times 10^{6}$ cells $/ \mathrm{ml}$, and were processed further for intracellular staining studies.

\section{Flow cytometric analysis}

Lymphocyte subsets were evaluated on whole fresh blood using different monoclonal antibodies (mAbs) panels. Two-colour and three-colour phenotypic characterizations of lymphocytes were performed as previously described. ${ }^{12}$ Briefly, $100 \mu$ of heparinized blood was incubated for $30 \mathrm{~min}$ on ice with the appropriate amounts of mAb. Cells were then lysed with buffer (FACS lysing solution; Becton Dickinson, Stockholm, Sweden) and analysed by flow cytometry (FACScan; Becton Dickinson). The lymphocyte gate was set using the log fluorescence of a two-colour $\mathrm{mAb}$ panel (Leukogate (anti-CD28 and anti-CD11 mAbs); Becton Dickinson) with linear $90^{\circ}$ side scatter. The resulting data were analysed with CellQuest software (Becton Dickinson).

\section{Purification of $\mathrm{CD}^{+}{ }^{+} \mathrm{T}$-cell subsets}

$\mathrm{CD}^{+}$cells were purified from lymphocytes by positive selection using anti-CD8 magnetic beads (Miltenyi Biotec, Sunnyvale, CA, USA) as we have recently reported. ${ }^{6}$ Sorting of $\mathrm{CD}^{+} \mathrm{CD} 28^{+} \mathrm{CD} 11 \mathrm{~b}{ }^{-}$, $\mathrm{CD}^{+}{ }^{+} \mathrm{CD} 28^{+} \mathrm{CD}_{11 \mathrm{~b}}{ }^{+}$, and $\mathrm{CD} 8{ }^{+} \mathrm{CD} 28^{-} \mathrm{CD} 11 \mathrm{~b}^{+} \mathrm{T}$ cells was performed from purified $\mathrm{CD}^{+}$lymphocytes stained with FITC-conjugated anti-CD11b (Immunotech, Marseille, France), PE-conjugated anti-CD28, and PerCP-conjugated anti-CD3, by flow cytometry (EPICS XL; Coulter Electronics, Hialeah, FL, USA). Only preparations with purity $>98 \%$ were used for experiments.

\section{Flow cytometric analysis of interferon gamma and interleukin-4 intracellular cytokine synthesis}

Intracellular cytokine detection was performed as previously described. ${ }^{6}$ Purified $\mathrm{CD}^{+}{ }^{+} \mathrm{T}$ cells were incubated in a medium containing phorbol myristate acetate $(50 \mathrm{ng} / \mathrm{ml})$, ionomycin $(100 \mathrm{ng} / \mathrm{ml})$ and monencin $(20 \mu \mathrm{M})$ (Sigma Chemical Co., St Louis, MO, USA) for $6 \mathrm{~h}$. Then $\mathrm{CD}^{+}{ }^{+} \mathrm{T}$ cells were collected and intracellular staining of interferon gamma (IFN- $\gamma$ ) and interleukin (IL)- 4 was performed by flow cytometry as previously described. ${ }^{6}$ Briefly, $\mathrm{CD}^{+}{ }^{+} \mathrm{T}$ cells were washed with PBS, supplemented with $0.5 \%$ bovine serum albumin (BSA) (GIBCO, Grand Island, NY, USA). After washing, cells were fixed with $4 \%$ formaldehyde for $15 \mathrm{~min}$ at room temperature, washed twice with PBS containing 0.5\% BSA and then permeabilized with PBS containing 0.5\% BSA and $0.5 \%$ saponin. Cells were incubated with PEconjugated anti-IL-4 or with FlTC-conjugated antiIFN- $\gamma$ MoAb. Cells were then washed with PBS containing $0.5 \%$ BSA and $0.5 \%$ saponin and next washed with PBS. Finally, cells were stained with biotin-labelled anti-CD8 MoAb, followed by RED670conjugated streptavidin. After washing with PBS, the 
samples were finally analysed with a flow cytometer and the percentage of cells expressing the cytokine were recorded.

\section{Lymphocyte adhesion to human microvascular endothelial cell cultures}

Primary cultures of human adrenal gland capillary endothelial cells (HACECs) were obtained as previously described. ${ }^{12}$ The endothelial cells were plated onto collagenated 96-well plates at a concentration of $5 \times 10^{3} /$ well in $100 \mu \mathrm{l}$ of endothelial basal medium (EBM) containing 10\% fotal calf serum, heparin (100 $\mu \mathrm{g} / \mathrm{ml})$, epidermal growth factor $(10 \mathrm{ng} / \mathrm{ml})$, and bovine brain extract ( $15 \mu \mathrm{g} / \mathrm{ml}$; EBM complete medium). The plates were incubated for $4-5$ days to obtain a monolayer. Endothelial cells were activated by adding tumour necrosis factor alpha (10 ng/ $\mathrm{ml})$ for $6 \mathrm{~h}$ at $37^{\circ} \mathrm{C}$. Cells were then washed with PBS and allowed to interact with purified $\mathrm{CD}^{+}$T-cell subsets $\left(2 \times 10^{4}\right.$ lymphocytes/well in RPMI 1640, containing $0.2 \% \mathrm{BSA})$. The plates were incubated for $2 \mathrm{~h}$ at $37^{\circ} \mathrm{C}$, and unbound lymphocytes were removed by three washes with warm PBS. The lymphocytes attached to endothelial cells were fixed for 5 min with $100 \mu \mathrm{l}$ of cold methanol, and the cells were stained with Diff-Quick (Merz-Dade, Dudingen, Switzerland) for $30 \mathrm{~min}$ at room temperature. Plates were then washed several times with deionized water, and the lymphocytes bound to endothelial cells were counted with a calibrated eyepiece in 15 different fields at $\times 200$ magnification. Each test was run in quadruplicate.

\section{Chemotaxis and migration assays}

All migration assays were performed in collagencoated 24-well Trans-well culture inserts $(6.5 \mathrm{~mm}$ diameter clear polycarbonate membrane with 3- $\mu \mathrm{m}$ pores; Costar, Cambridge, MA, USA). The medium used was RPMI 1640 containing 0.2\% BSA. All migration assays were conducted for $4 \mathrm{~h}$ at $37^{\circ} \mathrm{C}$. Purified CD8 ${ }^{+}$T-cell subsets $\left(2 \times 10^{5}\right)$ were placed in the upper chamber in $200 \mu \mathrm{l}$, and then $500 \mu \mathrm{l}$ of medium containing, or not, MIP- $1 \alpha$ was added in the lower well. The optimal chemotactic dose for MIP- $1 \alpha$ was $100 \mathrm{ng} / \mathrm{ml}$.

\section{Intracellular perforin staining}

After incubation of CD8 T cells with anti-CD28, and anti-CD11b, cells were fixed in paraformaldhehyde (4\% in PBS) for $15 \mathrm{~min}$ on ice, washed twice and permeabilized with saponin (0.1\% in PBS). Subsequently, cells were incubated with FITC-conjugated anti-perforin antibodies for $30 \mathrm{~min}$, washed twice again, and then analysed by flow cytometry.

\section{Statistical analysis}

Mann-Whitney $U$-tests were used to compare variables between two groups. Bonferroni's test was used for multiple comparisons. $p<0.05$ was considered statistically significant.

\section{Results}

\section{Intracellular cytokine analysis in $\mathrm{CD}^{+} \mathrm{T}$ cells}

Cytokine-producing $\mathrm{CD}^{+} \mathrm{T}$ cells were assessed in BD patients, compared with healthy controls, after stimulation for $12 \mathrm{~h}$ with phorbol myristate acetate and ionomycin at the single cell level, using intracellular cytokine staining and flow cytometry with twocolour analysis (Fig. 1). Samples obtained from unstimulated culture were negative for any of these
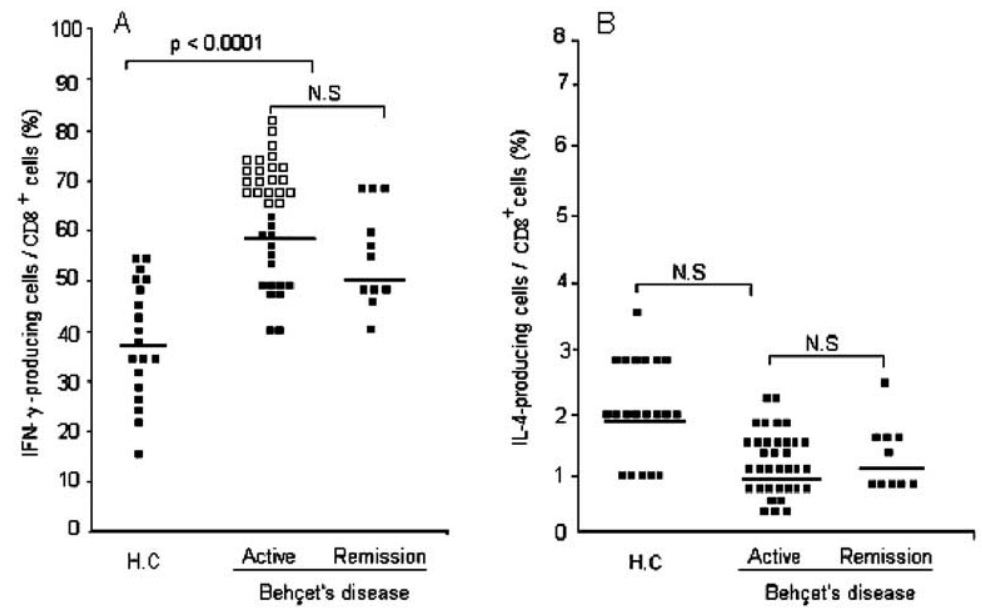

FIG. 1. Frequencies of $\mathrm{CD}^{+}{ }^{+}$T cells producing IFN- $\gamma$ and IL-4 in peripheral blood from BD in active and remission stage and from normal controls $(\mathrm{HC})$. Intracellular expression of IL-4 and IFN- $\gamma$ were determined by flow cytometry. Bars indicate the medians. Open squares, with central nervous system and pulmonary manifestations. (A) IFN- $\gamma$-producing cells. (B) IL-4producing cells. NS, not significant. 
cytokines. IFN- $\gamma$-producing $\mathrm{CD}^{+}{ }^{+} \mathrm{T}$ cells in active and remission $\mathrm{BD}$ patients were respectively more increased (median, 60\%; range, 40-79\%; median, $52.5 \%$; range, $40-70 \%)$ than normal controls (median, 37\%; range, 16-54\%; $p<0.001$ ) (Fig. 1A).

When BD patients were studied according to their clinical manifestations, the frequencies of IFN- $\gamma$ producing $\mathrm{CD}^{+}{ }^{+} \mathrm{T}$ cells were significantly higher in patients with pulmonary manifestations (median, 73\%; range, 70-79\%; $p<0.001$ ), and in patients with central nervous system manifestations (median, 76\%; range, 68-82\%), when compared with $\mathrm{BD}$ patients without these manifestations (median, 57\%; range, $40-63 \% ; p<0.05)$.

No significant difference was found in the proportion of IL4-producing cells among $\mathrm{CD}^{+} \mathrm{T}$ cells between BD groups and normal controls (Fig. 1B).

The Tc1:Tc2 ratio was evaluated from IFN- $\gamma$ to IL-4producing cells. The Tc1:Tc2 ratios of $\mathrm{CD}^{+}{ }^{+} \mathrm{T}$ cells in active (median, 14.5; range, 25.3-8) and remission BD patients (median, 12.9; range, 23.3-9.8; $p<0.05$ ) exhibited a drastic increase, when compared with control subjects (median, 8; range, 11.6-4). The Tc1:Tc2 were similar in BD patients in active and remission phases.

\section{CD28 and CD11b expression on $\mathrm{CD}^{+}{ }^{+} \mathrm{T}$ lymphocytes in BD}

Three subsets of $\mathrm{CD}^{+} \mathrm{T}$ lymphocytes $\left(\mathrm{CD} 28^{+}\right.$ $\mathrm{CD}_{11 \mathrm{~b}}{ }^{-}, \mathrm{CD}_{2}{ }^{+} \mathrm{CD}_{11 \mathrm{~b}}{ }^{+}$and $\left.\mathrm{CD}_{28}{ }^{-} \mathrm{CD}_{11 b^{+}}\right)$ were revealed as presented in Table 1 . In healthy controls, the $\mathrm{CD}_{11 \mathrm{~b}}{ }^{-}$prevailed over $\mathrm{CD} 11 \mathrm{~b}^{+}$subsets. The $\mathrm{CD} 28^{+} \mathrm{CD} 11 \mathrm{~b}^{+}$subset was barely present in healthy controls (median, 7.4; range, 5-8), when compared with active and remission $\mathrm{BD}(p<0.05)$. In patients suffering from active and remission $\mathrm{BD}$, we observed a significant increase in $\mathrm{CD}_{2}{ }^{-} \mathrm{CD} 11 \mathrm{~b}{ }^{+}$ cells $(p<0.01)$, when compared with the same subset in healthy controls. CD $28{ }^{+} \mathrm{CD} 11 \mathrm{~b}$ subset was highly expressed in healthy controls compared with active and remission BD patients $(p<0.01)$.

Table 1. CD28 and CD11b expression on $\mathrm{CD}^{+} \mathrm{T}$ lymphocytes from BD, compared with healthy controls

\begin{tabular}{llll}
\hline & $\begin{array}{c}\text { Healthy } \\
\text { controls }\end{array}$ & Active BD & Remission BD \\
\hline CD28 $^{+}$CD11b $^{-}$ & $72(59-78)$ & $37.2(32-40)^{\dagger}$ & $39(22-47)^{\dagger}$ \\
CD28 $^{+}$CD11b $^{+}$ & $7.4(5-8)$ & $22(15-35)^{*}$ & $20.5(29-46)^{*}$ \\
CD28 $^{-}$CD11b $^{+}$ & $19(12-24)$ & $36(27-44)^{\dagger}$ & $38(25-34)^{\dagger}$ \\
\hline
\end{tabular}

Staining with monoclonal antibodies to CD8, CD11b and CD28 with three-colour analysis. * Significant differences $(p<0.05)$ compared with the same subset of healthy controls. ${ }^{\dagger}$ Significant differences $(p<0.01)$ compared with the same subset of healthy controls.

\section{Adhesion of $\mathrm{CD}^{+}$T-cell subsets to HACECs, chemotaxis}

We investigated the adhesion of $\mathrm{CD} 28^{+} \mathrm{CD} 11 \mathrm{~b}{ }^{+}$and $\mathrm{CD}^{-} 8^{-} \mathrm{CD}_{11 \mathrm{~b}^{+}}$subsets to HACECs, both in healthy controls and in active $\mathrm{BD}$. In active $\mathrm{BD}$, $\mathrm{CD} 28^{-} \mathrm{CD}_{11 \mathrm{~b}^{+}}$cells adhere to HACECs at higher levels than the same subset in healthy controls $(p<0.05)$ (Fig. 2A). Both in BD patients and in healthy controls, the expression of CD11b molecules allowed $\mathrm{CD}^{+} \mathrm{CD} 28^{+} / \mathrm{CD}^{+} \mathrm{CD} 28^{-}$subsets to adhere to HACECs; the efficiency of the adhesion

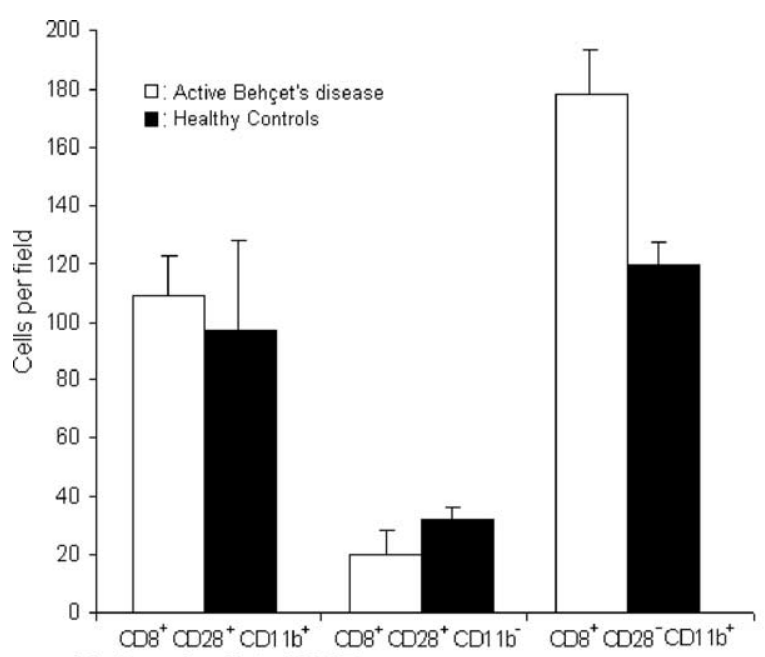

(A): binding of cells to HACEC

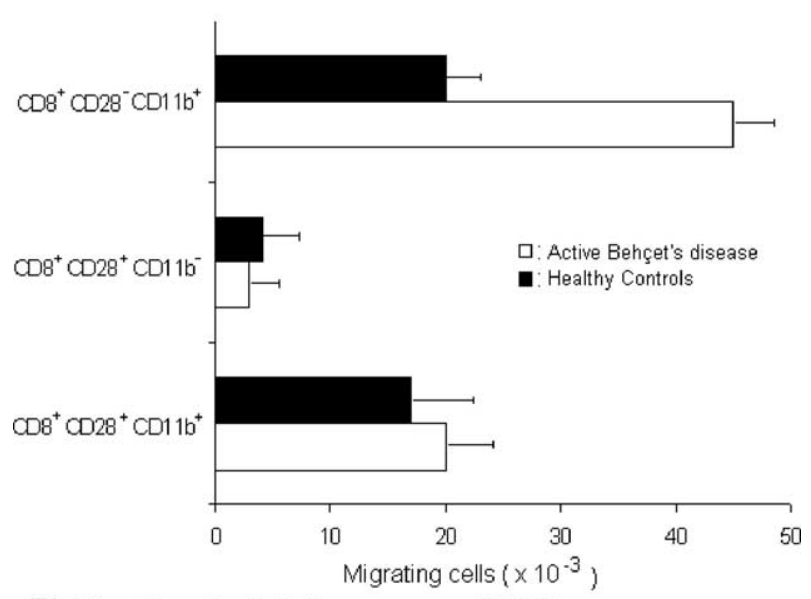

(B): Migration of cells in the presence of MIP-1 $\alpha$

FIG. 2. Function of $\mathrm{CD} 8^{+} \mathrm{CD} 28^{+/-} \mathrm{CD} 11 \mathrm{~b}^{+/-} \mathrm{T}$-cell subsets. (A) Binding to HACECs. Cells allowed to interact with a monolayer of tumour necrosis factor alpha-stimulated HACECs. Lymphocytes bound to HACECs were counted using a calibrated eyepiece in 10 different fields at $(\times 200)$ magnification. (B) Migration in active BD. The number of cells migrating into the bottom well in the absence or presence of MIP- $\alpha$ was evaluated by counting cells from duplicate wells. The net migration of cells was calculated by subtracting the number of cells migrating in the absence of a chemoattractant from the number of cells migrating in response to MIP-1 $\alpha$. Each test was run in quadruplicate. Bars represent the mean number of $\mathrm{CD} 8^{+} \mathrm{CD} 28^{+} \mathrm{CD} 11 \mathrm{~b}^{+}$, $\mathrm{CD} 8{ }^{+} \mathrm{CD} 28^{+} \mathrm{CD}_{11 \mathrm{~b}^{-},} \mathrm{CD}^{+}{ }^{+} \mathrm{CD} 28^{-} \mathrm{CD} 11 \mathrm{~b}^{+} \mathrm{T}$ cells per microscopic field \pm standard deviation. The experiments are representative of results obtained with cells from four healthy controls and seven active BD patients. 
was more important in $\mathrm{CD}^{+}$cells that have lacked CD28 antigen, particularly in active BD.

Using MIP-1 $\alpha$, we observed that both $\mathrm{CD} 28^{+} \mathrm{CD}_{11 \mathrm{~b}^{+}}$and $\mathrm{CD} 28^{-} \mathrm{CD} 11 \mathrm{~b}^{+}$from healthy controls and $\mathrm{BD}$ patients were efficiently attracted by the chemokine, whereas $\mathrm{CD} 28^{+} \mathrm{CD} 11 \mathrm{~b}{ }^{-}$cells were unable to respond to chemotactic stimulus (Fig. 2B). MIP- $1 \alpha$ is a $\beta$-chemokine that regulates T-lymphocyte migration from vessels to tissues. The migratory process of $\mathrm{CD}_{2} 8^{-} \mathrm{CD} 11 \mathrm{~b}^{+} \mathrm{T}$ cells is more important in active BD compared with healthy controls $(p<0.001)$.

\section{Perforin expression in $\mathrm{CD}^{+}$subsets}

We investigated intracellular perforin expression in the three $\mathrm{CD}^{+}{ }^{+}$subsets. Freshly isolated $\mathrm{CD} 8^{+}$cells were stained with anti-CD28, anti-CD11b, and antiperforin mAbs, and were analysed by flow cytometry. $\mathrm{CD} 28^{+} \mathrm{CD} 11 \mathrm{~b}^{-}$did not contain perforin both in healthy controls and patients with BD (median, 4\%; range, $0-6 \%$ ), while high staining was observed in the $\mathrm{CD} 28^{-}$population. $\mathrm{CD} 28^{-} \mathrm{CD} 11 \mathrm{~b}^{+}$exhibited an increased perforin expression in BD patients (median, 57\%; range, 33-62\%) compared with healthy subjects (median, 22\%; range, $12-34 \%)(p<0.01)$. In patients with $\mathrm{BD}$ and in healthy controls, $\mathrm{CD}_{2} 8^{+} \mathrm{CD}_{11 \mathrm{~b}}{ }^{+}$cells expressed similar levels of perforin (BD: median, 23\%; range, $11.5-27 \%$; healthy controls: median, 25\%; range, 9-24\%).

\section{Discussion}

In this study, intracellular cytokine analysis at the single cell level showed that the numbers of IFN- $\gamma$ producing CD8 $\mathrm{T}$ cells in active $\mathrm{BD}$ were increased compared with normal controls. In patients with $\mathrm{BD}$, and in healthy controls, $\mathrm{CD} 8^{+}$cells were exclusively producer of IFN- $\gamma$, they express insignificant IL- 4 cytokine level. The main source of IL- 4 were $\mathrm{CD} 4^{+}$ cells, as reported by Matsui et al. ${ }^{17}$ Evidence suggested that $\mathrm{BD}$ was characterized by an increased $\mathrm{Tc} 1 / \mathrm{Tc} 2$ ratio, in the same way as it has been reported in Th1/Th2 ratio. ${ }^{5,6}$ Th1(IFN- $\gamma$ ) cells are involved in the protection against intracellular parasites and delayed-type hypersensitivity, but they can cause autoimmune diseases. ${ }^{18}$ We have also demonstrated the occurrence of an unreported $\mathrm{CD} 8{ }^{+} \mathrm{CD} 28^{-}$T-cell subset in BD. The increase in such cells was not transient, as their percentage was highly expressed both in active and remission stages. The finding suggests the hypothesis that the presence of such cells during BD plays an important role in defence against a hypothetic aetiological agent. ${ }^{2-4}$ Recently, it has been reported that neuro-BD has a cytokine and chemokine pattern in resemblance with non- specific inflammations such as neuro-infections compared with autoimmune disorders. ${ }^{19}$ Circulating $\mathrm{CD} 8{ }^{+} \mathrm{CD} 28^{-} \mathrm{T}$ cells are increased not only in various infectious diseases ${ }^{20}$ but also in patients with autoimmune diseases. ${ }^{10}$ In rheumatoid arthritis patients, cytomegalovirus seropositivity has been directly correlated with increased levels of $\mathrm{CD} 8{ }^{+} \mathrm{CD} 28^{-} \mathrm{T}$ cells. ${ }^{21}$ Weeks et al. ${ }^{22}$ reported that functional virusspecific memory CTL clones are present in $\mathrm{CD} 8{ }^{+} \mathrm{CD} 28^{-} \mathrm{T}$ cells expressing or no CD57 marker (HNK-1). $\mathrm{CD}^{+}{ }^{+} \mathrm{CD} 28^{-} \mathrm{T}$ cells have been reported to be effector cells, producing perforin, granzyme B, tumour necrosis factor alpha and IFN- $\gamma{ }^{23,24}$

Although this is the first study to report an increase in the percentage of perforin-expressing $\mathrm{CD} 8{ }^{+} \mathrm{CD} 28^{-}$in patients with $\mathrm{BD}$, our study cannot provide conclusive evidence of perforin-cytotoxicity in $\mathrm{BD}$. Their relative cytotoxic potential must remain unclear since to date there are no studies that have satisfactorily addressed this question in BD. However, we have previously reported that patients with BD have elevated cytolytic $\mathrm{CD}^{+}{ }^{+} \mathrm{T}$ lymphocytes in peripheral blood against HSV1 target cells. ${ }^{25}$ Increased perforin expression has been reported in several other chronic inflammatory disorders with autoimmune phenomena such as multiple sclerosis, ${ }^{26}$ Takaysu's arthritis ${ }^{27}$ and Crohn's disease. ${ }^{28}$ In an animal model of lupus erythematosus, perforindeficient animals had more severe disease, suggesting that cytolytic lymphoid regulation plays a critical role in the immune homeostasis of these animals. ${ }^{29}$

One of the effects of IFN- $\gamma$ is to suppress the development of Th2 cytokines ${ }^{18,30}$ and point to the effector potential of $\mathrm{CD}^{+}{ }^{+} \mathrm{T}$ cells. ${ }^{31}$ IL- 4 prompts $\mathrm{CD}^{+}{ }^{-} \mathrm{T}$ cells to maintain CD28 expression in longterm cultures. ${ }^{32}$ The addition of IL- 4 led both the neonatal and the adult lymphocytes to keep their expression of $\mathrm{CD} 28{ }^{32,33}$ Besides, delayed addition of $\mathrm{IL}-4$ to $\mathrm{CD}^{+}{ }^{+} \mathrm{T}$ cell cultures did not re-induce CD28 on cells that have already lost the marker, indicating that IL- 4 can prevent, but cannot reverse, the switch in CD28 expression

Our BD data demonstrate that $\mathrm{CD} 8^{+}{ }^{-}$-cell differentiation into effector cells is characterized by acquisition of a CD $11 b^{+}$phenotype. Indeed, $\mathrm{CD} 28^{+} \mathrm{CD} 11 \mathrm{~b}^{-}$ cells are more similar in behaviour to true memory cells, being incapable of chemotaxis and adhesion to human microvascular endothelial cells, whereas their $\mathrm{CD} 11 \mathrm{~b}^{+}$counterpart has all the properties of fully competent effector cells. As suggested, the $\mathrm{CD} 28^{+} \mathrm{CD}_{11 \mathrm{~b}}{ }^{+}$subset provides a model for a critical step in the development of functional CTL, which precedes the process of $\mathrm{CD} 28$ downregulation. ${ }^{12}$ In functional terms, $\mathrm{CD} 8^{+} \mathrm{CD} 28^{-}$cells share features of both $\mathrm{CD} 28^{+}$and $\mathrm{CD} 28^{-} \mathrm{T}$ cells. $\mathrm{CD} 8^{+} \mathrm{CD} 28^{-}$cells are relatively resistant to apoptosis compared with their $\mathrm{CD} 8{ }^{+} \mathrm{CD} 28^{+}$precursors. ${ }^{34} \mathrm{CD} 8{ }^{+} \mathrm{CD} 28^{-}$have shorter telomers than $\mathrm{CD} 8{ }^{+} \mathrm{CD} 28^{+}$cells, indicating a 
history of increased cell divisions. ${ }^{35,36}$ The persistence of the expanded in vivo $\mathrm{CD}^{+}{ }^{+} \mathrm{CD} 28^{-}$subset may be explained by antigen-driven differentiation from $\mathrm{CD} 8{ }^{+} \mathrm{CD} 28^{+}$memory precursors, with relative resistance to apoptosis as the clones become perforinpositive effector cells. We have reported that patients with BD expressed high levels of soluble Fas/APO-1, which may be a useful marker in evaluating the extent of injury in vasculitis conditions. ${ }^{37}$ Patients with active $\mathrm{BD}$ expressed high levels of the bcl-2 in inflammatory sites, ${ }^{38}$ and the chronic inflammation in BD was confirmed by the increased amount of bcl-2 messenger RNA. ${ }^{39}$

Cells migrating to lymph nodes lack inflammatory and cytotoxic function, whereas cells migrating to peripheral tissues are endowed with various effector functions. ${ }^{40} \mathrm{CD} 11 \mathrm{~b}{ }^{+}$cells are present in blood; ${ }^{41}$ they have been described as an important molecule for the extravasation of neutrophils and monocytes to the site of inflammation - it is also involved in adhesion, chemotaxis, and diapedesis. ${ }^{42}$ Our report demonstrates an increase in the capacity of $\mathrm{CD} 28^{+}$ cells to migrate in response to MIP- $1 \alpha$ at the time that they acquire expression of CD11b, thus supporting the prospect of an effector $\mathrm{CD}^{+} 8^{+}$/ $\mathrm{CD}^{-} 8^{-}$subset with tissue-homing properties. Our BD patients, having pulmonary or central nervous system manifestations were characterized by expanded $\mathrm{CD}^{+}{ }^{+} \mathrm{CD} 28^{-} \mathrm{CD} 11 \mathrm{~b}^{+}$cells, which govern transition to the inflammatory sites. Such investigations allow us to manipulate cells for immunotherapy purposes. In our patients, the level of $\mathrm{CD}^{+}{ }^{+} \mathrm{CD} 28^{-} \mathrm{CD}_{11 \mathrm{~b}}^{-}$was scarcely represented. The biologic properties of $\mathrm{CD}^{+} \mathrm{CD} 28^{-} \mathrm{CD} 11 \mathrm{~b}{ }^{-} \mathrm{T}$ cells suggest that these cells might be end stage or aberrant differentiated effector cells. It has been reported that if $\mathrm{CD}^{+} \mathrm{CD}^{2} 8^{-} \mathrm{CD} 11 \mathrm{~b}{ }^{-} \mathrm{T}$ cells lacked cell-cell adhesion and impaired cytolytic functions, this would favour the hypothesis of a role for the development of immunodeficiency. ${ }^{43}$ Several observations suggest that the phenotypic evolutions detected in long-term cultures from healthy adult donors also occur in vivo: (i) $\mathrm{CD}^{+} \mathrm{T}$ cells with high, moderate and low CD28 density can be identified in normal adult blood; ${ }^{33}$ (ii) progressive emergence of $\mathrm{CD}^{+} \mathrm{CD}^{-} 8^{-} \mathrm{T}$ cells has been observed in healthy human adults, particularly but not exclusively in elderly subjects, and considerably more during many clinical situations associated with inflammation, chronic immune responses, ${ }^{44-46}$ where some pathogens, such as herpes simplex virus, ${ }^{47}$ cytomegalovirus and Epstein-Barr virus, ${ }^{34,48}$ are never eliminated, and maintenance of a high frequency of virus-specific $\mathrm{CD}^{+}{ }^{+} \mathrm{T}$ cells is essential to prevent viral reactivation from becoming symptomatic.

Our report suggests that the $\mathrm{BD}$ immune system reflects an autoimmune and/or viral situation, and $\mathrm{CD}^{+} \mathrm{T}$ cells acquire or lose markers according to the extended inflammatory process. We have shown a strong shift to Tc1 cells among $\mathrm{CD}^{+}{ }^{+} \mathrm{T}$ cells in peripheral blood from $\mathrm{BD}$ patients, the persistence of the expanded in vivo $\mathrm{CD}^{+}{ }^{+} \mathrm{CD} 28^{-}$subset, which may be explained by antigen-driven differentiation from $\mathrm{CD}^{+}{ }^{+} \mathrm{CD} 28^{+}$memory precursors, with relative resistance to apoptosis as these cells become perforin-positive effector cells. In general, it would be important for CD8 effector cells to avoid apoptosis. It undergoes repetitive antigen exposure when it serially kills one target after another. ${ }^{49}$ Perhaps this is the reason of the loss of CD28 and acquisition of CD11b expression in perforin-positive cells. Expansion of $\mathrm{CD}_{2} 8^{-} \mathrm{T}$ cells are not a distinctive feature of some special antigenic stimulation, but instead would merely reflect repeated stimulations of the BD immune system by any persisting antigen.

\section{References}

1. Direskeneli H. Review: Behçet's disease: infectious etiology, new autoantigens and HLA-B51. Ann Rheum Dis 2001; 82: 996-1002.

2. Direskeneli H, Saruhan-Direskeneli G. The role of heat shock proteins in Behçet's disease. Clin Exp Rheumatol 2003; 21(Suppl 30): S44-S48.

3. Eglin RP, Lehner T, Subak-Sharpe JH. Detection of RNA complementary to herpes-simplex virus in mononuclear cells from patients with Behçet's syndrome and recurrent oral ulcers. Lancet 1982; 18: 1356-1361.

4. Lehner T. The role of heat shock protein, microbial and autoimmune agents in the aetiology of Behçet's disease. Int Rev Immunol 1997; 14: $21-32$.

5. Raziuddin S, Al-Dalaan A, Bahabri S, Siraj A, Sedairy S. Divergent cytokine production profile in Behçet's disease. Altered Th1/Th2 cell cytokine pattern. J Rheumatol 1998; 25: 329-333.

6. Hamzaoui K, Hamzaoui A, Graïri H, Guemira F, Bessioud M, Hamza M, Ayed Kh. Cytokine profile in Behçet's disease. Scand J Rheumatol 2002; 31: $205-210$

7. Hamzaoui A, Graïri H, Ammar J, Zekri S, Guemira F, Hamzaoui K. IL-18 mRNA expression and IFN- $\gamma$ induction in bronchoalveolar lavage from Behçet's disease. Clin Exp Rheumatol 2003; 21: S8-S15.

8. Hislop AD, Gudgeon NH, Callan FCM, Fazou Ch, Hasegawa H, Salmon $\mathrm{M}$, Rickinson $\mathrm{AB}$. EBV-specific $\mathrm{CD}^{+}{ }^{+} \mathrm{T}$ cell memory: relationships between epitope specificity, cell phenotype, and immediate effector function. J Immunol 2001; 167: 2019-2029.

9. Hans-Willi Mittrücker, Kursar M, Köhler A, Hurwitz R, Kaufmann SHE. Role of $\mathrm{CD} 28$ for the generation and expansion of antigen-specific $\mathrm{CD}^{+}{ }^{+} \mathrm{T}$ lymphocytes during infection with Listeria monocytogenes. J Immunol 2001; 167: 5620-5627.

10. Schrimer M, Goldberger Ch, Wüzner R, et al. Circulating cytotoxic $\mathrm{CD} 8^{+} \mathrm{CD} 28^{-} \mathrm{T}$ cells in ankylosing spondylitis. Arthritis Res 2002; 4 : $71-76$.

11. Arosa FA. $\mathrm{CD}^{+} \mathrm{CD} 28^{-} \mathrm{T}$ cells: Certainties and uncertainties of a prevalent human T-cell subset. Immunol Cell Biol 2002; 80: 1-13.

12. Fiorentini S, Licenziati S, Alessandri G, et al. CD11b expression identifies $\mathrm{CD}^{+} \mathrm{CD} 28^{+} \mathrm{T}$ lymphocytes with phenotype and function of both naive/memory and effector cells. J Immunol 2001; 166: 900-907.

13. Nakata M, Kawasaki A, Azuma M, et al. Expression of perforin and cytolytic potential of human peripheral blood lymphocyte subpopulations. Int Immunol 1992; 4: 1049-1054.

14. Spaner D, Raju K, Radvanyi L, Lin Y, Miller RG. A role for perforin in activation-induced cell death. J Immunol 1998; 160: 2655-2664.

15. Muller S, Lory J, Corazza N, et al. Activated CD 4 and CD8 cytotoxic cells are present in increased numbers in the intestinal mucosa from patients with active inflammatory bowel disease. Am J Pathol 1998; 152: $261-$ 268.

16. International Study Group for Behçet's disease. Criteria for diagnosis of Behçet's disease. Lancet 1990; 335: 1078-1080.

17. Matsui M, Araya S, Wang H, Onai N, Matsushima K. Circulating subsets linked to intracellular cytokine profiles in normal humans. Clin Exp Immunol 2003; 134: 225-231.

18. Hartung AD, Bohnert A, Hackstein H, Ohly A, Schmidt KL, Bein G. Th2mediated atopic disease protection in Th1-mediated rheumatoid arthritis. Clin Exp Rheumatol 2003; 21: 481-486.

19. Saruhan-Direskeneli G, Yentur SP, Akman-Demir G, Isik N, Serdaroglu P. Cytokines and chemokines in neuro-Behçet's disease compared to 
multiple sclerosis and other neurological diseases. I Neuroimmunol 2003; 145: 127-134.

20. Callan MF, Tan L, Annels N, et al. Direct visualization of antigen-specific $\mathrm{CD}^{+} \mathrm{T}$ cells during the primary immune response to Epstein-Barr virus in vivo. J Exp Med 1998; 187: 1395-1402.

21. Hooper M, Kallas EG, Coffin D, Campbell D, Evans TG, Looney RJ. Cytomegalovirus seropositivity is associated with the expansion of $\mathrm{CD} 4^{+} \mathrm{CD} 28^{-}$and $\mathrm{CD} 8^{+} \mathrm{CD} 28^{-} \mathrm{T}$ cells in rheumatoid arthritis. $J$ Rheumatol 1999; 26: 1452-1457.

22. Weeks MP, Wills MR, Mynard K, Hicks R, Sissons JPG, Carmichael AJ. Large clonal expansions of human virus-specific memory cytotoxic $\mathrm{T}$ lymphocytes within the $\mathrm{CD} 57^{+} \mathrm{CD} 28^{-} \mathrm{CD} 8{ }^{+} \mathrm{T}$-cell population. Immunology 1999; 98: 443-449.

23. Gamberg J, Pardoe I, Bowmer MI, Howley C, Grant M. Lack of CD28 expression on HIV-specific cytotoxic T lymphocytes is associated with disease progression. Immunol Cell Bio l 2004; 82: 38- 46 .

24. Borthwick NJ, Lowdell M, Salmon M, Akbar AN. Loss of CD28 expression on $\mathrm{CD}^{+} \mathrm{T}$ cells is induced by IL-2 receptor $\gamma$ chain signalling cytokines and type1 IFN, and increases susceptibility to activation-induced apoptosis. Int Immunol 2000; 12: 1005-1013.

25. Hamzaoui K, Kahan A, Ayed Kh, Hamza M. Cytotoxic T cells against herpes simplex virus in Behçet's disease. Clin Exp Immunol 1990; 81: $390-395$

26. Rubesa G, Podack J, Sepcic J, Rukavina D. Increased perforin expression in multiple sclerosis patients during exacerbation of disease in peripheral blood lymphocytes. J Neuroimmunol 1997; 74: 198-204.

27. Seko Y, Minota S, Kawasaki A, et al. Perforin-secreting killer cell infiltration and expression of a $65-\mathrm{kD}$ heat-shock protein in aortic tissue of patients with Takayasu's arteritis. J Clin Invest 1994; 93: 750-758.

28. Muller S, Lory N, Corazza N, et al. Activated CD4 ${ }^{+}$and $\mathrm{CD}^{+}{ }^{+}$cytotoxic cells are present in increased number in the intestinal mucosa from patients with active inflammatory bowel disease. Am J Pathol 1998; 83: $1231-1236$.

29. Peng SL, Moslehi J, Robert ME, Craft J. Perforin protects against autoimmunity in lupus-prone mice. I Immunol 1998; 160: 652-660.

30. Lafaille JJ. The role of helper $\mathrm{T}$ cell subsets in autoimmune diseases. Cytokine Growth Factor 1998; 9: 139-135.

31. Kagi D, Ledermann B, Burki K, Zinkernagel RM, Hengartner $H$ Molecular mechanisms of lymphocyte-mediated cytotoxicity and their role in immunological protection and pathogenesis in vivo. Annu Rev Immunol 1996; 14: 207-212.

32. Labalette $\mathrm{M}$, Leteurtre $\mathrm{E}$, Thumerelle $\mathrm{C}$, et al. Peripheral human $\mathrm{CD} 8{ }^{+} \mathrm{CD} 28^{+} \mathrm{T}$ lymphocytes give rise to $\mathrm{CD} 28^{-}$progeny, but $\mathrm{IL}^{-} 4$ prevents loss of CD28 expression. Int Immunol 1999; 11: 1327-1336.

33. Lloyd TE, Yang L, Tang DN, Bennett T, Schober W, Lewis DE. Regulation of CD28 costimulation in human $\mathrm{CD}^{+}{ }^{+}$T cells. J Immunol 1997; 158 : $1551-1557$.

34. Posnett ND, James W, Edinger JW, Sanil Manavalan J, Irwin C, Marodon G. Differentiation of human CD8 $\mathrm{T}$ cells: implications for in vivo persistence of $\mathrm{CD} 8{ }^{+} \mathrm{CD} 28^{-}$cytotoxic effector clones. Int Immunol 1999; 11: 229-241.
35. Monteiro J, Battliwalla F, Ostrer H, Gregerson PK. Shortened telomers in clonally expanded $\mathrm{CD} 28^{-} \mathrm{CD} 8{ }^{+}$T cells imply a replicative history that is distinct from their $\mathrm{CD} 28^{+} \mathrm{CD}^{+}{ }^{+}$counterparts. J Immunol 1996; 156: $3587-3590$

36. Effros RB, Allsopp R, Chiu CP, et al. Shortened telomeres in the expanded $\mathrm{CD}_{28}{ }^{-} \mathrm{CD} 8^{+}$cell subset in HIV disease implicate replicative senescence in HIV pathogenesis. AIDS 1996; 10: F17-F22.

37. Hamzaoui K, Hamzaoui A, Zakraoui L, Chabbou A. Levels of soluble Fas/APO-1 in patients with Behçet's disease. Mediat Inflamm 1998; 7: $111-114$.

38. Hamzaoui A, Hamzaoui $\mathrm{K}$, Kooli $\mathrm{C}$ Chabbou A, Hentati F, Ayed Kh. High levels of bcl-2 protein in the T lymphocytes of patients with Behçet's disease. Clin Exp Rheumatol 1996; 14: 106-107.

39. Hamzaoui K, Hamzaoui A, Zakraoui L, Chabbou A. Expression of bcl-2 in inflammatory sites from patients with active Behçet's disease. Mediat Inflamm 1999; 8: 101-106.

40. Sallusto F, Lenig D, Forster R, Lipp M, Lanzavecchia A. Two subsets of memory $\mathrm{T}$ lymphocytes with distinct homing potentials and effector functions. Nature 1999; 401: 708-712.

41. Hoshino T, Yamada A, Honda J et al Tissue-specific distribution and age-dependent increase of human $\mathrm{CD}_{11 \mathrm{~b}}{ }^{+} \mathrm{T}$ cells. J Immunol 1993; 151: $2237-2241$.

42. Butcher EC. Cellular and molecular mechanisms that direct leukocyte traffic. Am J Pathol 1990; 136: 3-9.

43. Caruso A Fiorentini $\mathrm{S}$, Licenziati $\mathrm{S}$, et al. Expansion of rare $\mathrm{CD} 8{ }^{+} \mathrm{CD} 28^{-} \mathrm{CD}_{11 b^{-}} \mathrm{T}$ cells with impaired effector functions in HIV1-infected patients. J Acquir Immune Defic Syndr 2000; 24: 465-474.

44. Effros RB, Boucher N, Porter V, et al. Decline in $\mathrm{CD}_{2} 8^{+} \mathrm{T}$ cells in centenarians and in long-term T cell cultures: a possible cause for both in vivo and in vitro immunosenescence. Exp Gerontol 1994; 29: 601607

45. Mollet L, Sadat-Sowti B, Duntze J, et al. $\mathrm{CD} 8^{\text {hi }}{ }^{\mathrm{CD}} 57^{+} \mathrm{T}$ lymphocytes are enriched in antigen-specific $\mathrm{T}$ cells capable of down-modulating cytotoxic activity. Int Immunol 1997; 10: 311-316.

46. Borthwick NJ, Bofill M, Gombert WM, et al. Lymphocyte activation in HIV-1 infection. II. Functional defects of CD28 ${ }^{-}$T cells. AIDS 1994; 8: $431-435$.

47. Scotet E, Peyrat MA, Saulquin X, et al. Frequent enrichment for CD8 T cells reactive against common herpes viruses in chronic inflammatory lesions: towards a reassessment of the physiopathological significance of $\mathrm{T}$ cell Clonal expansions found in autoimmune inflammatory process. Eur J Immunol 1999; 29: 973-985.

48. Linsley PS, Ledbetter JA. The role of the CD28 receptor during T cell responses to antigen. Annu Rev Immunol 1993; 11: 191-197.

49. Griffiths GM. The cell biology of CTL killing. Curr Opin Immunol 1995; 7: $343-347$.

\section{Received 20 April 2004}

Accepted 28 May 2004 


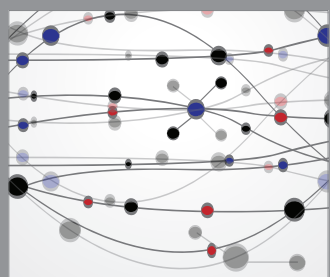

The Scientific World Journal
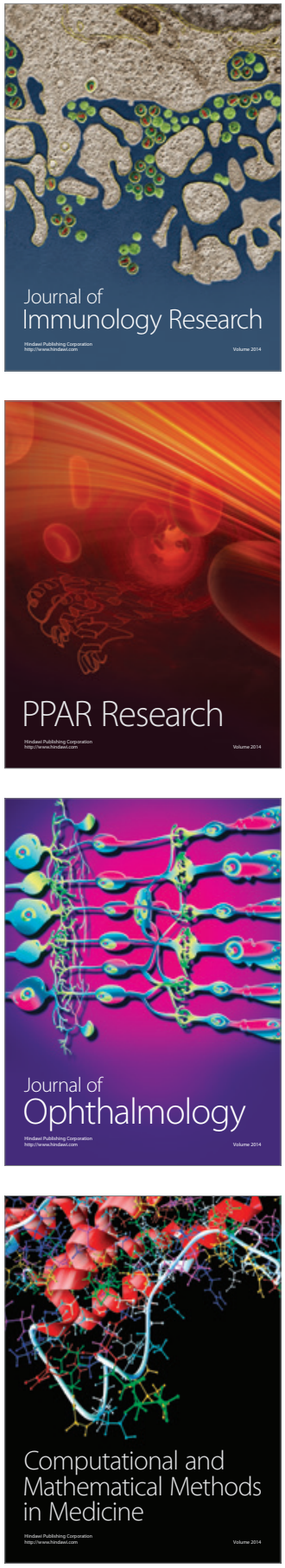

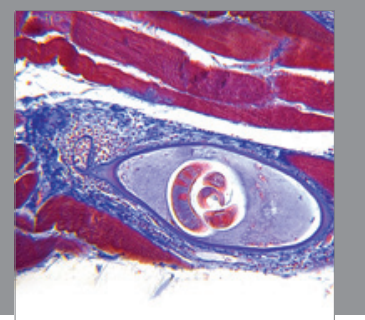

Gastroenterology

Research and Practice
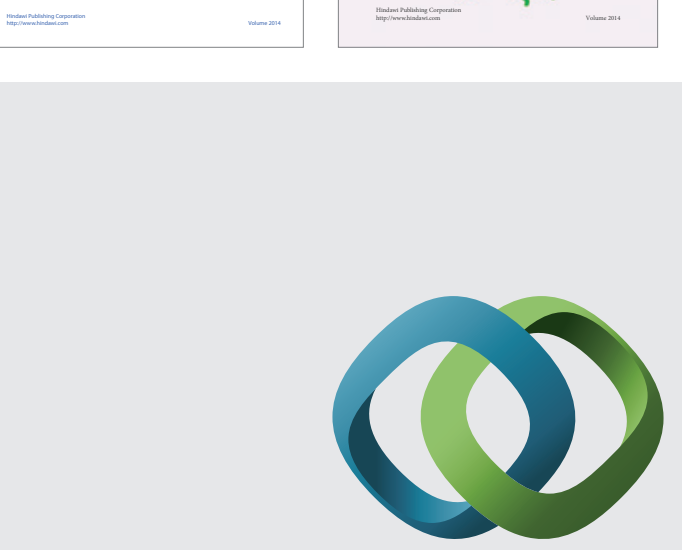

\section{Hindawi}

Submit your manuscripts at

http://www.hindawi.com
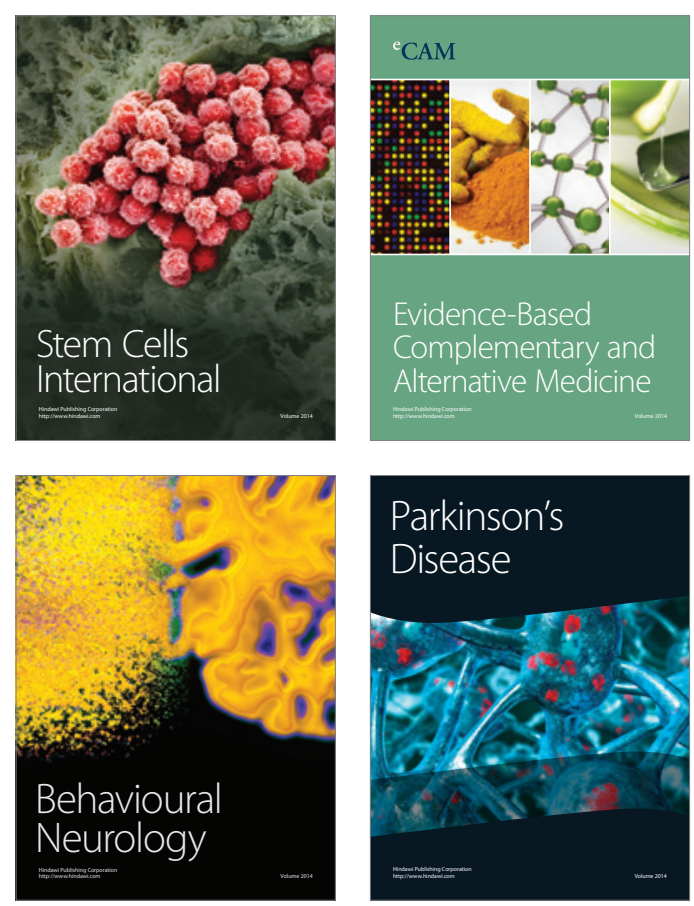

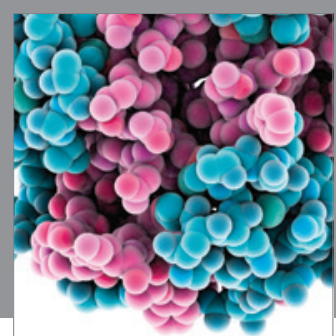

Journal of
Diabetes Research

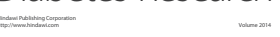

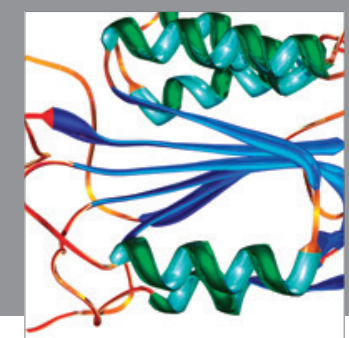

Disease Markers
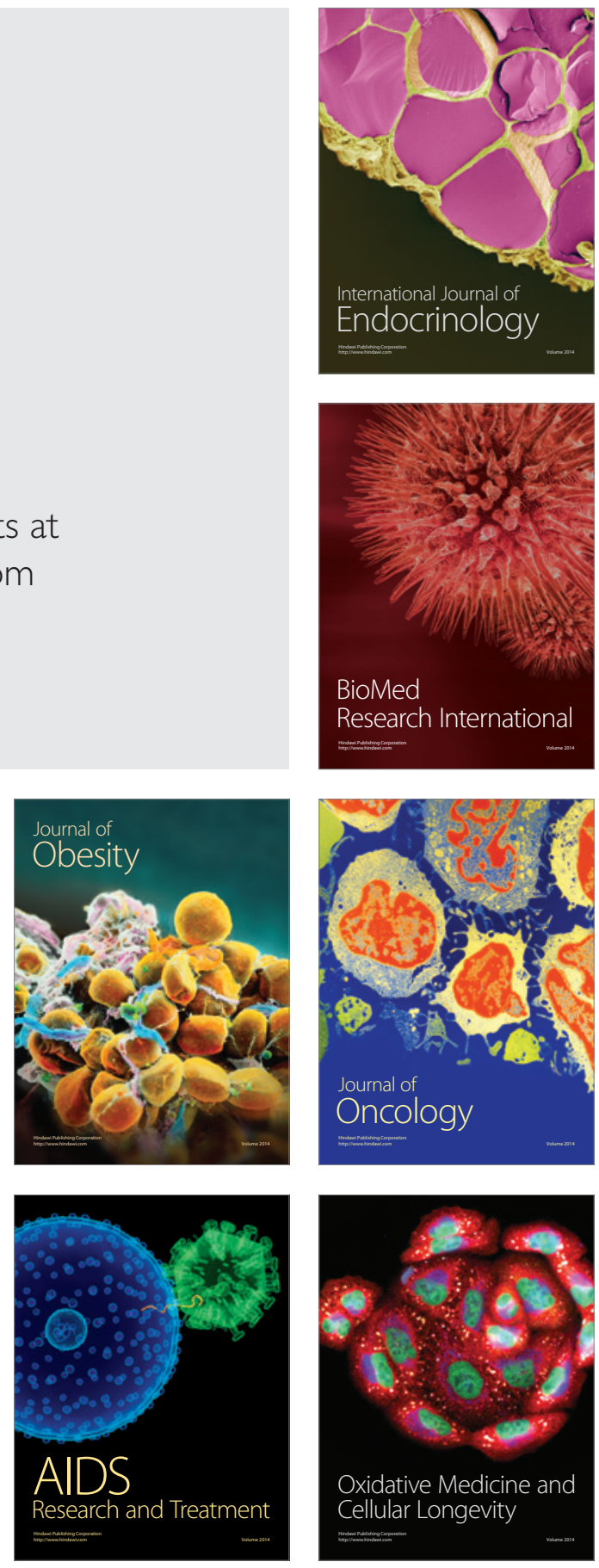